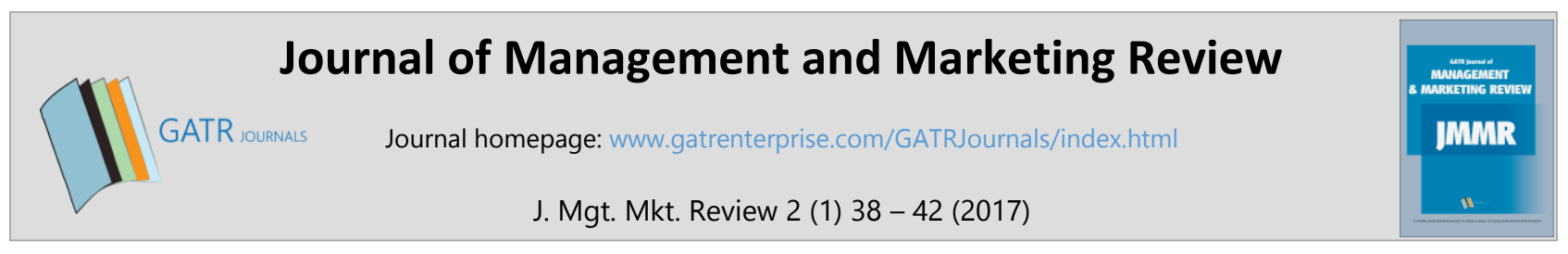

\title{
The Effectiveness of Information Architecture Design towards Brand Equity
}

\author{
Bunga Indah Bayunitri ${ }^{1^{*}}$ and Savitri Putri ${ }^{2}$ \\ ${ }^{1,2}$ Widyatama University, Bandung, Indonesia
}

\begin{abstract}
Objective - The paper aims to investigate the effectiveness of information architecture design towards brand equity in the case of GO-JEK company.

Methodology/Technique - Types of research are a descriptive analysis and causal also measuring a conclusion by using a regression analysis and for hypothesis testing using t-test and F-test. The results of this research indicated that information architecture design is effective and also has a significant influenced on brand equity.

Findings - The results show that design information architecture included in the criteria of "Highly Effective", this means that the customer respondents had a positive view of the effectiveness of design information GO-JEK architecture by using these indicators: The Principle of Object, Choice, Disclosure, Exemplars, Fronts-Doors, Multiple Classification, Focused Navigation, and Growth.

Novelty - The study suggests that brand equity is influenced by the effectiveness of the design information architecture, then what should be done is the creation of effective information architecture.
\end{abstract}

Type of Paper: Empirical

Keywords: Application; Brand Equity; Effectiveness; Information Architecture Design; Online Service; Transportation. JEL Classification: M15, M31, M37.

\section{Introduction}

Transportation service is an important means for the community to facilitate various activities such as school, work, travel, and so on. The transportation service business is also having a significant increase in the competition so that businesses should be able to provide various types of services that differ from their competitors in order to attract consumers and use their services. The consumers are becoming more selective in making purchase decisions because there are lots of different types of transport services and the types of services offered to them.

Increased competition in the transportation services business was not separated from the increasing use of the Internet and increasingly sophisticated technological tools. By offering online services using applications

\footnotetext{
* Paper Info: Received: January 21, 2017

Accepted: March 17, 2017

* Corresponding author:

E-mail: bunga.indah@widyatama.ac.id

Affiliation: Widyatama University, Bandung, Indonesia
} 
on smartphones based on Android and iOS, it is easier for consumers in the transportation booking service to make a purchase.

Currently, the online transport services in Indonesia who had entered the service are based on motorcycles and cars. There are several companies that entered these fields that have a large customer base in Indonesia, namely PT GO-JEK, Uber, and Grab.

PT. GO-JEK Indonesia is a transportation company that originated from Indonesia with socially minded technology with partnering with approximately 200,000 motorcycle riders who are experienced and trusted in Indonesia, they provide various services, including transport and food delivery.

Danar (2016) identified that PT GO-JEK Indonesia launched Go-Jek application in January 2015, and it has been downloaded 500,000 times. The global research institute, Growth for Knowledge (GfK) Indonesia, released the data of best application-based transport services online and the most widely used in Indonesia is GO-JEK. Total GO-JEK application users reached $21.6 \%$ of the total users of other technology applications in Indonesia.

GO-JEK has officially operated in 10 major cities in Indonesia, including Jakarta, Bandung, Bali, Surabaya, Makassar, Yogyakarta, Medan, Semarang, Palembang and Balikpapan with development plans in other cities in the coming year. The services available are shuttle service using motorcycles and cars, courier service, food and drink deliveries, and other consumer goods. There are some other additional services such as cleaning services (for private rooms, houses, offices, etc.), massages, salon, tickets, and others.

However, Adrian (2015) said that behind the success of GO-JEK products related to the use of the application, there are some disadvantages that until now has not been resolved, such high latency (The weak responses obtained by the user on the application due to a surge in the number of users, while the capacity of its servers does not yet support it. So that the application is experiencing slow response is particularly true in the rush hour. Also, there is the hidden order that is quite disturbing for the user because the order was not followed up. So users sometimes have to wait for hours to get their services, but in fact, the order is not in the application. Also, there is an error of navigation map and security gap that will certainly harm the Go-Jek. For example, if the Go-Jek driver has a community like Prize Hunter, they can play fraud with the help of fellow drivers Go-Jek with how the Go-Jek driver to play "pickup order-and-finish" in a short time and in a day they could gain millions of rupiah without having to go anywhere.

If the shortcomings as mentioned above cannot be resolved properly then there will be a decline in their brand equity that will directly impact on a number of their sales. Therefore, they need a good system in order to regulate and organize all the information requirements needed to use good information architecture design.

Spencer (2010) stated that Information Architecture (IA) is all about organizing content or things, describing them clearly and providing ways for people to get to them. A lot of information architecture work relates to websites and intranets but is just as relevant for music and movies, a computer file system, your paper files at home or even groceries on supermarket's shelves.

And to understand IA, Brown (2010) suggested some principles to help it, are: The principle of objects (content as tangible objects has its place, has a lifecycle, has a characteristic, has the equipment, function, purpose and structure), the principle of choice (about the options that can be granted to users, the Principle of disclosure (allows the user to get the information), the principle of exemplars (grouping of menu that allow a user to search), the principle of fronts doors (possible for the user to be able to directly visit the web page without having to go through the home page), the principle of multiple classification (offering some kind of a different classification for users to access the website content), the principle of focused navigation (involves all areas of the website pages), and the principle of growth (the concept of content growth like this would indicate that the website will continue to evolve to provide the information required by the user).

Milaminora (2016) stated that Go-Jek is already implementing a system of e-business in the marketing process. Event marketing is done by placing a flyer on the website of the company, partners, social media, and any other electronic media. Also posted a video on youtube where the ad when someone presses the ad will automatically go directly to the company's website. 
The concept of marketing states that in order to achieve organizational goals depends on determining the needs and wants of the target market, satisfy customers more effectively and efficiently than competitors (Kotler \& Armstrong, 2015).

The company's marketing process will be more profitable if the company is already well-known brand. Brand equity is the amount of assets and liabilities related to the brand, its name, and symbol, which increase or decrease the value of the products or services for the company or for its customers (Aaker, 1996). Brand equity is the added value given to products and services. Brand equity can be reflected in the way customers think, feel, and act in conjunction with the brand, as well as price, market share, and profitability, given, the brand for the company (Kotler \& Keller, 2012).

GO-JEK has done a good marketing with online and offline media, but it has not been established clearly the perception GO-JEK for his customers. Moreover, the current number of competitors are entered in the same field, then how about the customer loyalty. According to Aaker (1996), the main elements of brand equity in the last four, namely brand awareness, brand association, perceived quality, and brand loyalty.

Based on the aforementioned background, the problems can be formulated as follows: What is the effectiveness of information architecture in the GO-JEK application based on customer's perceptions? How is the customer's perception of the brand equity that owned by GO-JEK? And how big is the positive influence on the effectiveness of the information architecture on brand equity in the GO-JEK application?

\section{Methods}

The method used in this research is a descriptive method. As stated by Sugiyono (2011):"descriptive research is a study that aims to provide or describe a situation or phenomenon that occurs at this time by using scientific procedures to address the actual problems".

The technique used in this study is associative hypothesis testing of correlation and regression analysis. According to Ghozali (2006), testing simultaneous effect is used to determine whether the independent variables jointly or simultaneously affect the dependent variable. Simultaneous testing using the F distribution is compared between $\mathrm{F}$ arithmetic with $\mathrm{F}$ table with significance level of 5\%. Criteria for testing the hypothesis that Ho accepted if $\mathrm{F}$ arithmetic $<\mathrm{F}$ table at $\alpha=5 \%$, Ho is rejected if $\mathrm{F}$ count $>\mathrm{F}$ table at $\alpha=5 \%$.

Theoretical sampling size is done by applying theory mentioned by Hair et al (2006) that: "The ratio between the number of subjects and the number of independent variables in the multivariate analysis is recommended around 15 to 20 subjects per independent variable."

$\mathrm{n}=$ multivariate analysis $\mathrm{x}$ the number of independent variables or sub-variables

$\mathrm{n}=15 \times 8=120$ (minimum of 120 respondents)

Sampling using purposive random sampling (Sugiyono, 2008), which is a sampling process to first determine the number of samples to be taken that meet the following criteria:

a) Bandung citizen;

b) Have a smartphone based on Android or iOS;

c) User of GO-JEK application.

\section{Result}

The results show that design information architecture included in the criteria of "Highly Effective", this means that the customer respondents had a positive view of the effectiveness of design information GO-JEK architecture by using these indicators: The Principle of Object, Choice, Disclosure, Exemplars, Fronts Doors, Multiple Classification, Focused Navigation, and Growth. 
The Principle of Exemplars is the indicator with the highest score, this means that the customer feels that the systematic preparation of group menus and sub menus can be easily read and searchable. The preparation of the systematic design of the possibility of using a variety of specific symbols that can facilitate the application GO-JEK users to find information they need.

The results show that brand equity is included in the criteria of "Very High", this means that the customer respondents had a positive view of brand equity of GO-JEK by using these indicators: Brand Awareness, Brand Association, Perceived Quality and Brand Loyalty.

Brand Association is an indicator with the highest score, which indicates that the memory of customers to the brand GO-JEK is very high. This is possible because the brand GO-JEK is the first online-based public transport services utilizing mobile application and its existence is quite phenomenal in Indonesia. It is directly proportional to the confidence of customers to the brand GO-JEK that progressively increasing due to the reduction of initiative customer complaints quickly by their owners for services provided is increasing.

Testing the hypothesis for presence or absence of significant positive effect on the effectiveness of information architecture design to brand equity of GO-JEK testing the correlation and causality between variables.

The result shows that the coefficient of determination was $68.2 \%$, which means a change in the GO-JEK brand equity amounted to $68.2 \%$ influenced by the effectiveness of the design information architecture. While, the rest $31.8 \%$ is explained by other factors. Here is a summary of hypothesis testing results seen in the table below:

Based on the above hypothesis testing, we can see that tcount $>$ ttable $(15.897>1.66)$ and Fcount $>$ Ftable (252.727 > 3.07) means it can be concluded that the decision of the third hypothesis, H0 and H1 accepted meaning a positive influence on the effectiveness of the design information architecture of the GO-JEK brand equity.

It signifies that in order to improve brand equity, GO-JEK heavily dependent on the creation of design information architecture that is capable with the aim to help facilitate the application users in finding and understanding the information they need.

If the design of information architecture can be implemented effectively it will indirectly improve the wellbeing and achieve business goals, one of which to increase profitability. Profit can be achieved as a result of their loyalty to keep using the same brand and not switch to the other competitors.

\section{Discussion}

Based on the results of data processing and discussion, the authors conclude the study are as follows: the effectiveness of the design information architecture of GO-JEK rated by respondents included in the category of "Highly Effective", meaning that the customer respondents had a positive view of the effectiveness of the GO-JEK design information architecture. One indicator that has a positive value is an indicator of respondents, The Principle of Exemplars an indicator with the highest score, this means that the customer feels that the systematic preparation of group menus and sub menus can be easily read menus and searchable. The preparation of the systematic design of the possibility of using a variety of specific symbols that can facilitate the users to find the information they need.

In connection with the effectiveness of the design information architecture, there are indicators that still has inherent limitations related to the information in the application GO-JEK, which is still quite difficult to grasp because of the high complexity of the information requires several stages in the search for information in the information classification scheme. The thing about it is advisable to hire an expert in the field of information architecture design from content and context of the application GO-JEK experienced and competent in their field.

The brand equity of GO-JEK rated respondents fall into the category of "Very High", this means that the customer respondents had a positive view of GO-JEK brand equity. Brand Association is one indicator of brand equity to gain the highest score, which shows that the memory of customers to the brand GO-JEK is 
very high. This is possible because the brand GO-JEK is the first online-based public transport services utilizing mobile application and its existence is quite phenomenal in Indonesia.

Brand loyalty is one of the indicators that need to be considered in this study because it had the lowest scores on the variables of brand equity. This indicates that their customers are likely to switch to a competitor's brand was considered quite high. Therefore, it is highly recommended if you want to survive and increase customer loyalty it must dare to invest in technology. The sophistication of the technology will bring more businesses quick, accurate, and practical. Thirdly it is necessary for the customer based online applications. In addition, in order to more loyal customers, improve service quality by adding some additional services. For example, ease of method of payment services, not only to use cash but can use a credit card, debit card, even T-money or other digital money.

The effectiveness of information architecture design is a positive influence to GO-JEK brand equity. This indicates that in order to improve brand equity GO-JEK heavily dependent on the creation of design information architecture that is capable with the aim to help facilitate the application users in finding and understanding the information they need.

Regarding GO-JEK, brand equity is influenced by the effectiveness of the design information architecture, then what should be done is the creation of effective information architecture. One advised to GO-JEK is to implement Customer Relationship Management (CRM)-based cross-functional enterprise system in which to integrate and automate customer service processes in sales, marketing, and service of the products or services related to the company, such acquire (to get customers using direct marketing techniques by performing the direct promotion in social media), enhance (add subscribers using the technique of cross sell and up sell that is working with partner companies who want to use the service GO-JEK so that it can increase the number of new customers), and retain (keep loyal customers or customer support using a technique in which companies respond to any complaints and desires of consumers so that companies can create a loyal customer).

\section{References}

Aaker, D. A. (1996). Measuring brand equity across products and markets. California management review, 38(3), 102120.

Ghozali, Imam. (2006). Statistik Nonparametrik. Semarang: Badan Penerbit UNDIP.

Hair Jr, J.F., Black, W.C., Babin, B.J., Anderson, R.E. \& Tatham R.L. (2006) Multivariate data analysis (6th ed.) Pearson-Prentice Hall, Upper Saddle River, NJ

Kotler, P. \& Armstrong, G. (2015). Marketing an Introducing (12th ed.). England: Pearson Education, Inc.

Kotler, P. \& Keller, K. L. (2012). Marketing Management (14th ed.). New Jersey: Pearson Education, Inc.

Spencer, D. (2010). A Practical Guide to Information Architecture. United Kingdom: Five Simple Steps.

Sugiyono. (2008). Metode Penelitian Kuantitatif, Kualitatif dan R\&D. Bandung: Alfabeta.

Sugiyono. (2011). Metode Penelitian Pendidikan. Bandung: Alfabeta.

Brown, D. (2010). Eight Principle of Information Architecture. Bulletin of the America Society for Information Science and Technology. 36 (6), 30-34.

Adrian, N. (2015). GO-JEK: Fenomena dan Kelemahannya. Retrieved from http://blog.novanadrian.com/go-jekfenomena-dan-kelemahannya/

Dono, D. (2016). Survei: Gojek Ungguli Grab. Retrieved from http://teknologi.news.viva.co.id/news/read/748464-surveigojek-ungguli-grab

Milaminora. (2016). Sistem Informasi Manajemen Studi Kasus Go-Jek. Retrieved from https://milaminora.wordpress.com/2016/02/13/sistem-informasi-manajemen-studi-kasus-go-jek-2/ 